Article

\title{
The Map to the Heart: An Analysis of Political Affectivity in Turkey
}

\author{
Tereza Capelos ${ }^{1, *}$ and Stavroula Chrona ${ }^{2}$ \\ ${ }^{1}$ Institute for Conflict, Cooperation and Security, University of Birmingham, Birmingham, B15 2TT, UK; \\ E-Mail: t.capelos@bham.ac.uk \\ 2 Department of European and International Studies, King's College London, London, WC2B 6NR, UK; \\ E-Mail: stavroula.chrona@kcl.ac.uk \\ * Corresponding author
}

Submitted: 14 May 2018 | Accepted: 23 October 2018 | Published: 28 December 2018

\begin{abstract}
This study examines the complexity of citizens' political affectivity in Turkey. Drawing from componential models of affect, we rely on situational (motive consistent versus inconsistent) and motivational state (gain or loss) appraisals to test hypotheses on systematic differences in the clusters of political affect that span beyond the traditionally measured discrete emotional reactions of anger, hope, pride and fear. Using qualitative interview data from 2012, we develop a topography of affect clusters and systems of associations between political concepts. We find citizens express their emotionality in rich terms. They are linked to appraisals of multiple political objects, they reflect aversive, anxious, loss and gain oriented emotional responses, and they are guided by citizens' ideological orientations. This study is valuable as it addresses a significant gap in the study of political affect going beyond their discrete categorizations. It introduces a mapping methodology as an effective way of capturing the complexity of affect systems, and it reveals powerful insights into the depth and richness of emotions based on appraisal dimensions, enriching our understanding of political tensions and developments in Turkish politics and beyond.
\end{abstract}

\section{Keywords}

affect; appraisals; cognitive affective maps; emotions; ideology; interviews; political affectivity; Turkey

\section{Issue}

This article is part of the issue "Interdisciplinary Approaches to Studying Emotions within Politics and International Relations", edited by Alex Prior (University of Leeds, UK) and Yuri van Hoef (Utrecht University, The Netherlands).

(C) 2018 by the authors; licensee Cogitatio (Lisbon, Portugal). This article is licensed under a Creative Commons Attribution 4.0 International License (CC BY).

\section{Introduction}

This study examines the complex affectivity of political orientations in Turkey. Recent developments in this deeply divided society make it an excellent place to study political affect. During the Gezi protests in 2013 diverse segments of the public came to the streets against the AKP's authoritarian system of governance; calling for social justice against the increasing restrictions on individual rights and freedoms (Bee, 2017; Öniş, 2015). The Gezi movement brought together people from diverse backgrounds, who shared individual grievances and hopes, fears and frustrations, and appeared to overcome ideological boundaries that traditionally set them apart (Bee \& Kaya, 2017; Chrona \& Bee, 2017; Göle, 2013; Öniş, 2015; Özdemir, 2015).

Expressions of anger, fear, hope, frustration and pride during that time were frequent in interpersonal interactions, social media and various online blogs ${ }^{1}$. International news and academic studies reported on the raised levels of emotionality in Turkish politics but the discussion of these emotions took for granted their origins and content (BBC, 2013; Mullen \& Cullinane, 2013; Odağ, Uluğ, \& Solak, 2016). In an original set of studies, Erisen

\footnotetext{
${ }^{1}$ See Facebook groups Gezi Solidarity, Diren Gezi Parki and Taksim solidarity, and Twitter hashtags \#direngeziparki, \#occupygezi, \#direnturkiye, \#direnistanbul \#direndunya, \#direnankara, \#direnizmir, \#DuranAdam which hosted Gezi related tweets.
} 
$(2013,2017)$ tested the impact of anger, fear and enthusiasm on public attitudes of Turkish citizens towards their leaders, least liked groups in society, social mobilization, and risk perception related to ISIS and Syria. He found that these emotions were responsible for changes in citizens' 'risk assessments, threat perceptions, policy evaluations, information seeking, premiership approval and performance evaluations' (2013, p. 131). These findings highlight the value of the study of emotions in Turkey and generate new pressing questions. What gave rise to these emotions? What did these emotions 'mean' for the citizens that experienced them, and to which considerations were they attached? As we cannot assume a 'common citizen' reacting to political events, we also should not assume common experiences of anger, fear, hope or pride. Their content should be investigated to understand the origins of political actions and reactions.

Our study uses qualitative in-depth interview data from 2012 in Turkey to provide valuable insights on citizens' affective experiences. Because these experiences are rich, fluid and ever changing, we prefer the analytical category of affect, which contains emotions, but also moods, feelings, sentiments, and emotional traits (Capelos \& Demertzis, 2018; Thagard, 2012). We explore under what conditions they arise and assist individuals to make sense of politics. We also take into account ideological dispositions to examine citizens' differential accounts of political events. As we show, uncovering the origins of political affectivity allows us to appreciate variation in political action and reaction. Our approach can be extended to examine the affective profile of recent spikes in unconventional participation or the controversial electoral outcome of 2018 in Turkey which has been characterized as following a downward turn to authoritarianism (Chrona \& Capelos, 2017; Esen \& Gümüşçü, 2017; Tansel, 2018; White \& Herzog, 2016).

\section{Modelling Affective Experiences: Complex Reactions beyond Anger and Fear}

Affect is one of the three mental functions alongside cognition and motivation (Reber, 1985, p. 15). As a general term affect is often used interchangeably with emotions but in essence affect is a fundamental functional category that concerns or arouses the emotional root of judgements and beliefs (Barrett, 2006). It is important to understand affective processes because together with cognition they drive thinking and decision-making (Damasio, 1994; Fazio, Sanbonmatsu, Powell, \& Kardes, 1986; Fiske \& Taylor, 1984). Emotions, feelings, sentiments and moods are all affect types combining cognitive appraisal and psychological perception (Thagard, 2012). Emotions, like love, hate, anger, fear, hope and pride are acute and momentary expressions of affect, which originate from cognitive appraisals and evaluations of the environment; they are bound to social expectations, and result in physiological changes that prepare an individual for action (Capelos, 2013).
In contrast to moods, which usually last longer, emotions are brief and distinct affective experiences. In addition, emotions are directed towards something, while moods are general and can have combined sources. Feelings refer to our conscious experience of our emotions but at times they can also be imperceptible. Sentiments (our likes and dislikes) and emotional traits last longer, but sentiments are directed towards an object while traits are personality characteristics and are generally directed at the world (Damasio, 2003; Frijda, 1994).

The spectrum of our affective experiences is approached by theories of basic emotions which identify a set number of discrete emotions each with distinctive patterns, like anger joy, fear, enthusiasm; by circumplex model theories (Russell, 1980) which propose the classification of affect along two key dimensions of arousal and valence; and componential models (Frijda, 1986) that see emotions sharing particular configurations on appraisal dimensions which can be grouped together (Ekman, 2003). Barrett (2006) points out that the boundaries between similarly-valenced discrete emotions are not as distinct as is usually assumed. Emotions fit a combination of appraisal clusters, which share co-relational themes (Lazarus, 1991).

Componential models explore these themes further and offer a topography of affect. The key mechanism for the elicitation of different emotions are the appraisals of the event as motive inconsistent or consistent (situational state), whether it involves a punishment or reward (motivational state), whether it is uncertain or certain (the event's probability), whether it is perceived as weak or strong (power) whether its negative or positive outcome is deserved (legitimacy) and whether the event is caused by circumstances, another person or the self (agency) (Frijda, 1986; Roseman, Spindel, \& Jose, 1990; Scherer, 2005). Emotions are linked to combinations of appraisals (Scherer, 1984) and can bind together in affective clusters (Ekman, 2003). Motive inconsistent affect involves aversive emotions like anger and irritation which arise as response to the appraisal of an event seen as obstruction or infringement to reaching a goal or satisfying a need, with a possible action tendency to attack (Scherer, 2001). They also involve fear, worry and anxiety, the anxious affectivity cluster which unlike aversive affect, are generated in situations involving threat, demonstrating the tendency to withdraw to avoid contact (Frijda, 2004). Motive inconsistent is also affect generated in situations where the opportunity to obtain a reward is either lost or absent, experienced as sadness and disappointment (Sabini \& Silver, 2005). Motive consistent joy and pride are elicited when the motivational appraisal of an event is beneficial, reward eliciting, within reach and deserved. Motive consistent situations with uncertain outcomes linked to the anticipated termination of a motive inconsistent event are experienced as hope (Roseman et al., 1990).

The study of appraisals raises the question of the temporal primacy of emotion versus cognition, which is dif- 
ficult to settle. While some scholars assume the impact of emotions on evaluations of concepts, others note that the arrows can point inward, where the appraisals of concepts give rise to the emotions (Clore \& Ortony, 2000). In addition, Lazarus, Kanner and Folkman (1980) note the high level of fluidity of affect: the same event may be appraised and reappraised in different ways over time, producing differing affective experiences. To complicate matters further, the experience of specific, distinct emotions arises partly from cultural knowledge about emotions (Barrett, 2006). This links to studies that show that emotions implicate social experiences and are the result of social interaction (Hochschild, 1979). Socially enacted emotions like compassion, embarrassment, shame, humiliation and guilt concern our personal identity as it relates to others. We also experience collective emotions that involve our social identity and generate shared experiences, strengthen social bonds but can also carve out rigid boundaries between 'us' and 'them'. Collective emotions are experienced in the plural, and like individual emotions, take specific expressions of anger, shame, pride, hope, fear and disappointment (Hatfield, Caccioppo, \& Rapson, 1994; Rime, 2007; Ross, 2014). Moreover, the 'me' and the 'us' are interconnected as they arise from our interactions with the social and political environment (Bar-Tal, Halperin, \& de Rivera, 2007; Capelos, Exadaktylos, Chrona, \& Poulopoulou, 2018; Jost, Nam, Amodio, \& Van Bavel, 2014).

\section{Complex Political Affectivity and Citizens' Preferences}

The above highlights that our experience of affect in politics, in other words our political affectivity, is dynamic, relational, ambivalent and often contradictory (Capelos, 2013; Demertzis, 2013). Individual, social and collective political experiences give rise to discrete emotions, but also moods, feelings and sentiments, which often bind together as individuals describe how they feel. When we only measure citizens' individual discrete emotions and their effect on political decisions, we take a narrow approach that ignores the links between the experience of clusters of emotions and their associated cognitive representations. Our starting hypothesis is that affective experiences emerge from a variety of political concepts. Although moods, sentiments and feelings are often sidestepped in the examination of political affectivity due to the methodological domination of instruments that focus on discrete emotion measures, we postulate that citizens' political affectivity is richer and broader than quantitative survey accounts can capture. Hence, we test this hypothesis by using qualitative data, focusing on two key appraisal dimensions (situational and motivational state). Our analyses identify clusters of emotions, moods and feelings and their interconnections with salient political concepts that make up citizens considerations about politics.

Our first hypothesis is that aversive affectivity like anger, disgust, annoyance, or frustration will be associated with negative reactive attitudes towards political objects (Capelos, 2013). Aversive affectivity carries discontent and punishment related tendencies and promotes action without much deliberation. Anxious affectivity such as worry, uneasiness and fear is associated with avoidance and risk aversion behavioural patterns with the aim to reduce exposure to the source of anxiety so our second hypothesis is that it will relate to concepts that denote exposure to stressful stimuli but not inspire action. Third, in accordance with studies in psychology, we expect that sadness and disappointment will be related to the activation of memories of other misfortunes and failures and to ebbing away from any urge towards action (Frijda, 1994). Enthusiasm, joy and pride generate participatory practices and trust towards institutions, hope promotes altruism, and combined with efficacy promotes action readiness. Our fourth hypothesis is that pride will be observed when events are appraised as motive consistent and reward eliciting, and hope will be observed with the anticipated termination of motive inconsistent events (Capelos, Katsanidou, \& Demertzis, 2017; Ekman, 2003; Frijda, 1986).

\section{Ideological Orientations as Drivers of Political Affectivity}

Different people in the same situation feel different emotions (Roseman et al., 1990). We therefore look beyond individual preferences to ideological orientations to understand differentiation in the sources of affectivity. Political ideology, being an externally generated, socially shared system of competing beliefs about the way society should function, structures individual thinking and responses, which in turn influence social and political reality (Conover \& Feldman, 1984; Converse, 1964; Lane, 1962; Sniderman, Brody, \& Tetlock, 1991). Ideological orientations serve as foundations of individuals' mental structures: a pool of connotations that links motive consistent evaluations with preferred ideological inclinations, and motive inconsistent ones with least-preferred ideological principles (Markus \& Zajonc, 1985).

In Turkey, the ideologies of Kemalism and political Islam dominate the socio-political structure ${ }^{2}$. The Kemalist inheritance advocated by centre-left CHP, embedded in the Constitution the secular and modern driven nature of Turkey. The neoliberal version of political Islam, advocated since 2002 by $A K P$, has tried to reconcile modernity and a version of conservative neoliberalism with Islamist principles (Ciddi, 2009; Gülalp, 2001; Kaya, 2015; Özbudun, 2006; Somer, 2007; Uyusal, 2011; Yavuz, 2006, 2009).

\footnotetext{
2 Political Islam and Islamism refer to the political connotation of Islam and influence of religion in the socio-political arena. Political Islam is 'a form of instrumentalization of Islam by those pursuing political objectives. It provides political responses to today's societal challenges by imagining a future, the foundations for which rest on reappropriated, reinvented concepts borrowed from the Islamic tradition' (Denoeux, 2002, p. 61).
} 
The nature of the ideological changes of the main advocators of political Islam and Kemalism have been thoroughly examined (Çarkoğlu, 2002, 2007; Taniyici, 2003; Yavuz, 2006). In addition, public opinion research offers complex models that point to the long-standing effects of the existing dichotomies and social cleavages as well as factors that shape citizens' electoral choices and political behavior such as centre vs. periphery, left-right ideology, political values, core personal values, economic considerations, education, interest and knowledge and ethnic and collective identity (Akarca \& Tansel, 2007; Arikan, 2013; Başlevent, Kirmanioğlu, \& Şenatlar, 2009; Çarkoğlu \& Hinich, 2006; Çarkoğlu \& Kalaycioğlu, 2007; Erdoğan \& Uyuan-Semerci, 2017; Ergünder, 1980-1981; Erisen, 2016; Esmer, 2002; Kentmen-Çin, 2015; Mardin, 1973; Toros, 2014; Yilmaz, Sarıbay, Bahçekapılı, \& Harma, 2016). However the interplay between ideological orientations and political affectivity has been underexplored in the Turkish context. Our hypothesis here is that motive consistent affectivity such as hope and pride will occur for concepts (parties, actors and issues) which align with an individual's system of beliefs. We also expect that motive inconsistent affectivity expressed as anger, frustration, disappointment, sadness, fear, worry, anxiety and uneasiness, will arise with concepts that contradict ideological inclinations.

\section{Methodology}

To test the above hypotheses, in-depth interviews were conducted in Istanbul with native Turkish citizens between July and September 2012 using snowball sampling $^{3}$. Thirty-eight participants from diverse educational and socio-economic backgrounds were invited and twenty-five agreed to participate ${ }^{4}$. The interviewer spoke Turkish and English fluently and fourteen participants chose to speak Turkish while eleven opted for English, switching to Turkish as needed. The average duration of the interviews was 1 hour and 25 minutes and the overall duration of the recorded material was approximately 32 hours.

At the start of the interview a short survey measured demographics and ideological placement on three 7-point scales (Kemalism vs. political Islam, left vs. right orientations, and liberalism vs. conservatism) and participants were invited to discuss their responses. As the interview progressed to a general discussion of politics, participants were asked what made them feel as they did when they mentioned affect terms (discrete individual or collective emotions, moods, sentiments and feelings). We recorded their responses verbatim and identified the specific affect mentions.

Next we grouped affect items together in five clusters-families based on their key appraisal dimensions (situational and motivational state): motive consistent gain-related pride, joy, satisfaction, and admiration; motive consistent loss-avoidance related hope, expectation and anticipation; motive inconsistent aversive affectivity with expressions of anger, frustration, rage and irritation; motive inconsistent anxious affectivity with expressions of fear, worry, concern, uncertainty, and insecurity; and motive inconsistent loss-related disappointment, distrust, dismay, sadness, and pessimism. Based on our hypotheses we anticipated patterns in the concepts that were mentioned in reference to these emotions.

We organized the data using a variant of Cognitive Affective Maps (CAMs), which displays in diagrams the conceptual and emotional structure of people's views (Homer-Dixon, Milkoreit, Mock, Schroder, \& Thagard, $2014)^{5}$. CAMs are used in psychology, cultural anthropology, sociology and political science, to describe cultural thought and action-potential for individuals and groups (Thagart, 2012) ${ }^{6}$. We created a master map (Figure 1) with concepts mentioned in relation to how participants felt about politics, and maps for each of the five affective clusters highlighting only the concepts mentioned in relation to the cluster (Figures 2 to 6).

Because our aim was to test hypotheses regarding the rich cognitive explanations of political affectivity (beyond positive and negative affect), our maps divert from traditional CAMs in three ways. First, the main frames are the affective clusters, so instead of identifying valence between concepts, the specific affective clusters are linked with the concepts that gave rise to them. The maps represent the main affect frame as the platform on which the related concepts are activated (rather than using lines to connect shapes). Second, our maps do not provide a comprehensive account of concepts related to Turkish politics. Instead, we focused on concepts associated with how participants felt about politics. Third, our maps do not account for associative strength because it was not possible to assess this reliably from our qualitative interviews.

\footnotetext{
${ }^{3}$ Snowball sampling (non-probability) relies on referrals from initial subjects to identify hard-to-reach subjects, when materials are sensitive. Snowball and respondent-driven samples can provide asymptomatically unbiased estimates (Salganik \& Heckathorn, 2004; Snijders, 1992).

${ }^{4}$ Of the 25 participants, 20 (80\%) were $18-29$ years old and $5(20 \%)$ were $30-49$ years old; 14 were men (56\%) and 11 were women (44\%); most were employed in the private sector (tourism, private tutors, bank, school teachers) and 2 unemployed; $88 \%$ obtained or were studying for an undergraduate or postgraduate degree and $12 \%$ had a high school degree; $64 \%$ were middle class, $20 \%$ upper-middle, and $16 \%$ lower- middle; $60 \%$ voted for CHP, $24 \%$ for AKP voters, $8 \%$ for MHP and $8 \%$ for TKP.

${ }^{5}$ CAMs visualize citizens' cognitive and affective conceptual structures (Homer-Dixon et al. 2014; Thagard \& Findlay, 2014). The main frames (key concepts) connect into a network that represents systems of beliefs, with links highlighting complex associations. Changes in associative strength (weak or strong) vary the thickness of the line that connects the main frames, and changes in valence (positive or negative) vary the colour of shapes (green for positive, red for negative). CAMs track the affective framework tagged to the respective cognitive process and allow for the evaluation of emotional coherence by modelling the associative power of positive and negative values, which can change or remain constant across individuals (Thagard, 2006).

${ }^{6}$ CAMs have been used in small-N studies (see Wolfe, 2011, interviews with 25 participants), as well as analyses of negotiations and documents (see Findlay \& Thagard, 2014; Homer-Dixon et al., 2014).
} 


\section{Findings}

Our overall hypothesis was that affect is experienced in a variety of complex and fluid formulations rather than a handful of emotions like anger, fear or hope. In our interviews we identified 259 affect mentions expressed as individual and collective emotions, feelings, moods and sentiments, grouped into five affect clusters on the basis of their situational and motivational state appraisals. The richness of our data suggests that using a few discrete emotion labels to identify citizens as 'angry', 'afraid', 'or 'enthusiastic', ignores more nuanced expressions of individual and collective affect. In addition limiting the affective content of concepts to 'positive' and 'negative,' does not do justice to citizens' complex affective worlds.

Our first CAM examined the origins of all affective mentions and showed that they were linked to a variety of political objects: political leaders and parties, religion, current affairs, issues such as individual rights and freedoms, oppression, and social and political stability versus change (Figure 1). Next, we analysed each affect cluster separately and identified the concepts linked specifically to each one (Figures 2 through 6). Our aim was to examine whether affective reactions originate from a common core of concepts or differ in content based on their appraisal dimension.

Our second and third CAMs examined motive consistent affect like pride, admiration, joy and hope. Fig- ures 2 and 3 show them linked with favourable ideological orientations and party preferences. The justifications offered by the interview participants regarding the way they felt pointed to motive consistent ideological orientations and objects congruent with their preferences and vote choices. Figures 4,5 and 6 highlight the particularities of motive inconsistent affect, and its links with unfavourable ideological orientations, issues and political actors. On the whole, we noticed that participants reported affect that span across the five dimensions confirming our theoretical expectations. In addition, their affective experiences were rich and at times ambivalent. For example symbols like the flag or the picture of Ataturk inspired pride but also worry, the AKP governance tactics were a source of hope but also anger, actions that undermine democracy were linked to anger, fear, worry and disappointment.

Focusing specifically on motive consistent affect, we expected that gain-related and loss-avoidance affectivity would have different origins (Figure 2 and 3 respectively). Motive consistent, gain-related affective expressions such as pride, joy and enthusiasm, were mentioned 28 times mostly for the Turkish flag and/or the picture of Mustafa Kemal Ataturk (Figure 2). They were also linked to secularization and modernization values, the nation, and ideological party preferences. More specifically, eleven participants reported feeling proud when looking at the Turkish flag, considering it a significant

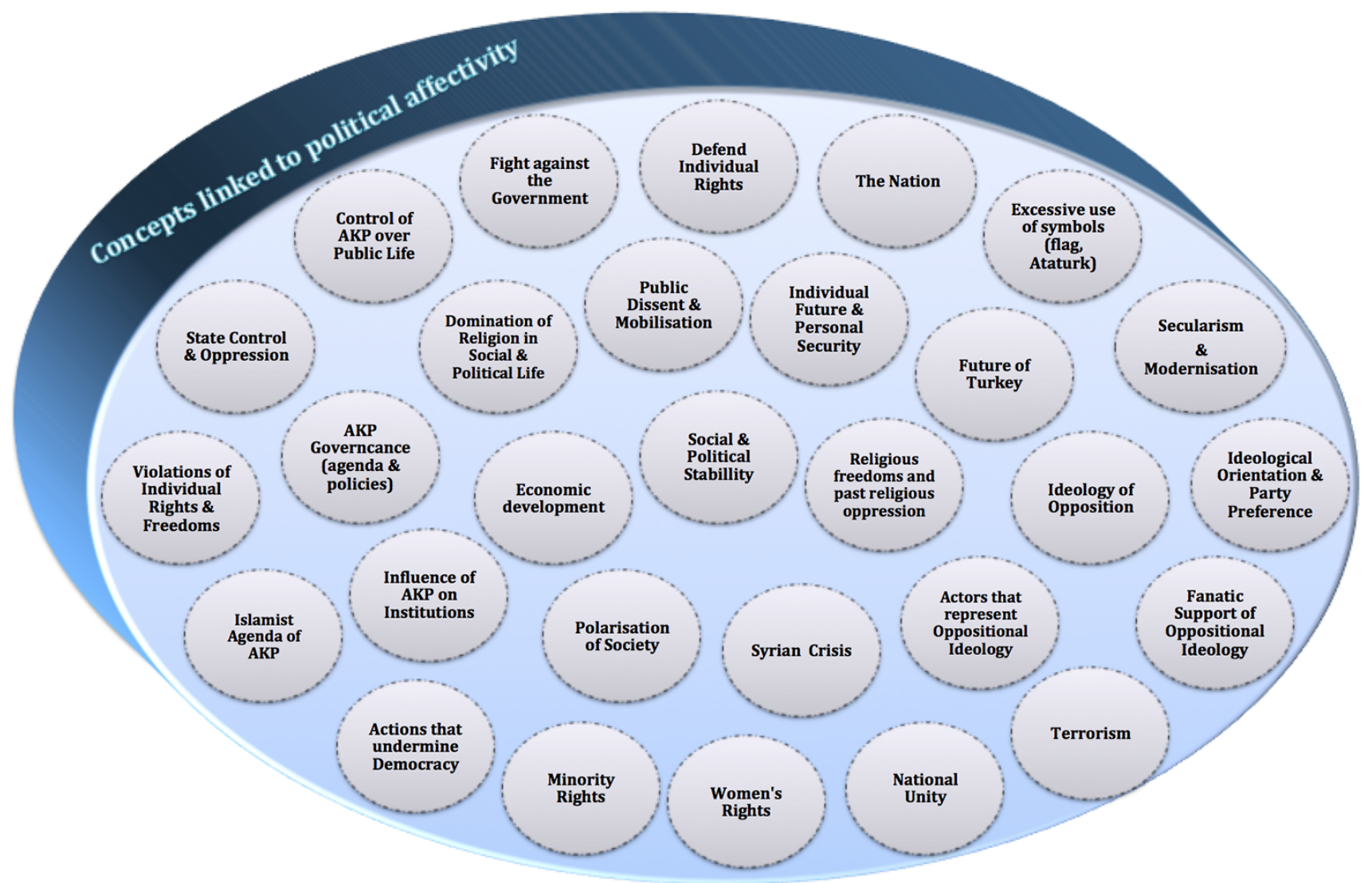

Figure 1. Map of concepts linked to political affectivity. 
symbol for them and the society. Four AKP supporters viewed it as a national symbol of unity, combined with religion. Two MHP supporters focused on the significance of the flag for Turkish citizens and national unity. For six CHP supporters the flag brought pride and admiration for the secularist ideas it represents.

Motive consistent, gain-related pride appeared in complex interactions with motive inconsistent affect. Four participants indifferent about the flag or the picture of Ataturk when they were in Turkey, felt pride when seeing them abroad. For some others, the excessive use of both symbols generated anger and disappointment. Others experienced ambivalence: nine noted that although they felt proud for the Turkish flag and the picture of Ataturk, their excessive use created negative feelings. In the words of P5:

Especially in the last years you can see the flag pretty much everywhere. Although I am proud to be Turk, seeing the flag in every place doesn't make me feel comfortable. You know it resembles with very negative situations where the flag dominates all spheres of life.

Motive consistent loss-avoidance considerations giving rise to hope, were mentioned 16 times, and linked to opposing government practices, supporting freedoms and rights, and future economic development (Figure 3). AKP supporters hoped that conservative AKP forces (representing the Islamists) would not dominate the party and the country's future, and that AKP would continue the positive change in society and harmonize social relations, 'ending the domination of conservative Kemalists'. The country's economic development under the AKP rule also created hope among these participants. For AKP opponents however, hope had a different meaning. Characteristically one participant (P1) noted:

To walk down the streets promoting our rights...it's the only hope we have left and the only tool we have against Erdoğan and AKP.

Ten CHP supporters felt hopeful when discussing the role of CHP's socio-democratic agenda as the sole opposition to AKP. Two MHP voters were hopeful that their party leader (Bahçeli) would enhance the party's position as a constructive opposition to the AKP. Two extreme-left supporters, disappointed with Turkish politics hoped for the creation of a new party to be the real oppositional force against the AKP governance.

Next, we turned to motive inconsistent affectivity (Figures 3, 4 and 5). All three motive inconsistent affective clusters (aversive, anxious and loss-related) were linked to state control and oppression; violation of individual rights and freedoms; the policies, agenda and influence of AKP; actions that undermine democracy; the

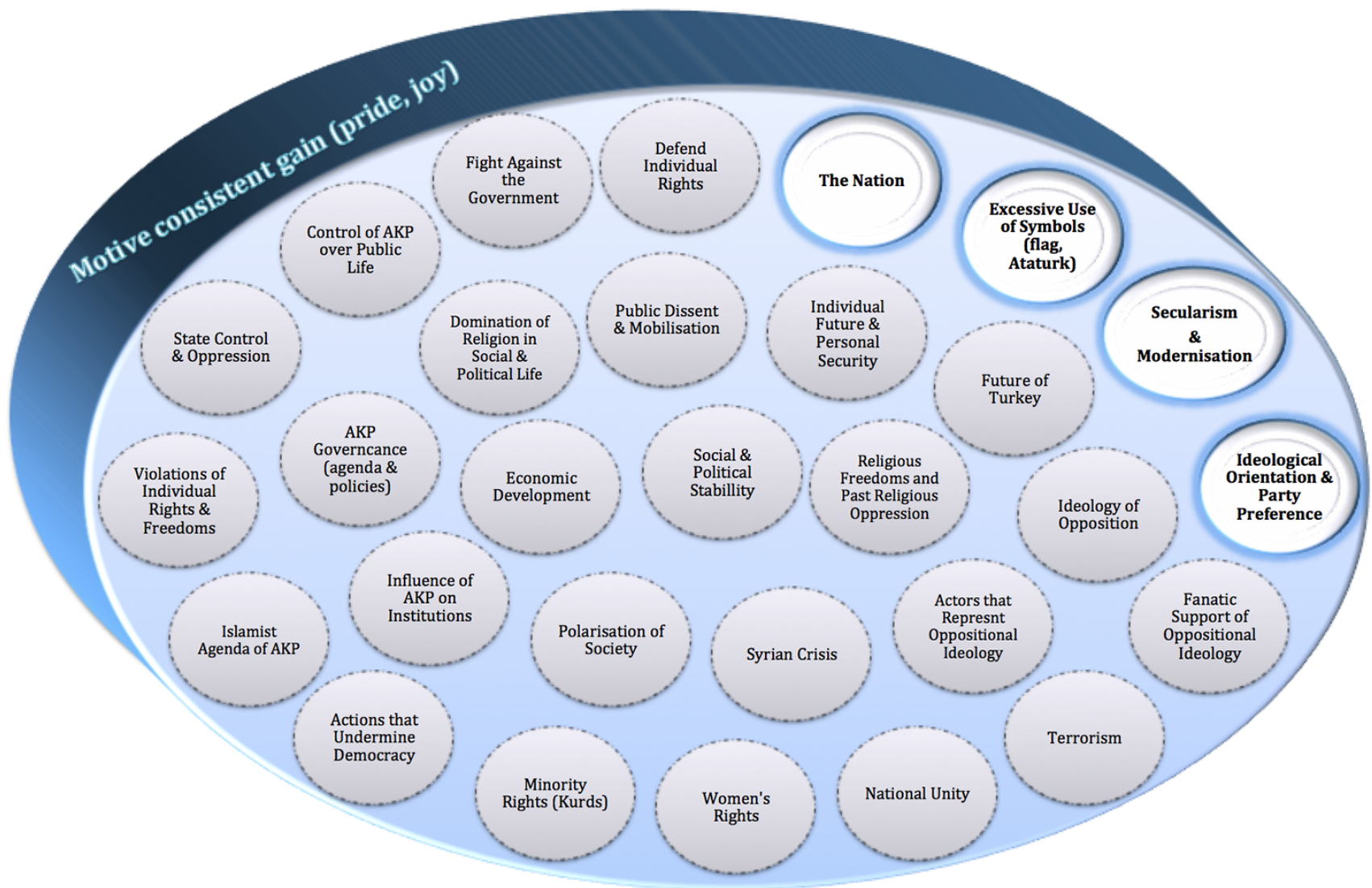

Figure 2. Map of motive consistent gain-related affect. 


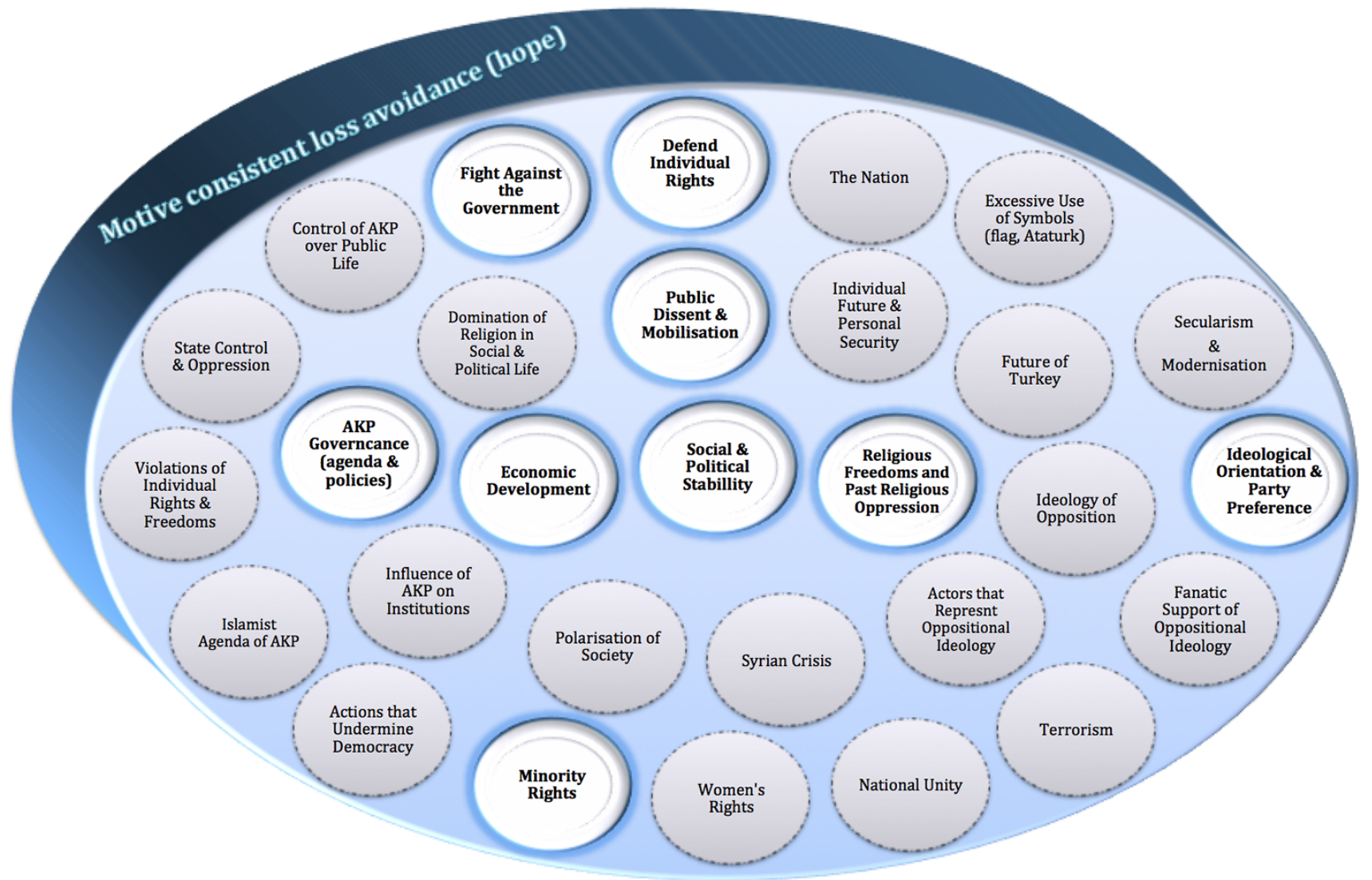

Figure 3. Map of motive consistent loss-avoidance related affect.

future of the country; past religious oppression; oppositional ideologies and societal polarization. This highlights the value of the question we posed early on: what are the mechanisms and origins that underlie affective phenomena.

Looking specifically at the map of aversive affect in Figure 4, anger, frustration, annoyance, rage and irritation were mentioned 113 times, in discussions of dominant ideologies, key political actors, certain policies, democratic principles and individual freedoms and rights as well as state-generated oppression.

About 17 participants expressed aversion for the dominant ideological orientations and their key political advocators. They disliked the AKP attempts to promote the party as agent of conservative neoliberalism while violating individual rights and freedoms. Two were frustrated with the AKP Islamist agenda and the aim 'to convert the Turkish state into a conservative Islamic state'. Four were angry with the control of the judiciary, the media and the armed forces. Kemalist supporters disliked the 'false promises about democracy', the 'limitation of personal freedoms and rights', and the increased role of religion. According to P23 (CHP voter):

I get really angry when I hear that AKP is a party promoting human rights and freedom. Come on. AKP is a party that has taken a series of measures that go against public rights and freedoms in the name of its religious conservative agenda. It is governing the country by oppressing individuals, reducing our freedoms and generating a widespread feeling of fear.

Five were angry with conservatives' disapproval of public behaviours like drinking or women smoking, and three mentioned individual rights restrictions with examples of friends or relatives being under investigation or prosecuted. Six were averse to AKP's power to silence oppositional voices, and five were frustrated with the 'neverending conflict' between supporters of political Islam and Kemalism. The socio-political environment and the pressure from political Islam and Kemalism were sources of anger, and also loss-related affect like deep disappointment, sadness and pessimism about the future of Turkey. We see here clear evidence of affective experiences spanning across the motive inconsistent clusters.

Two participants were angry with fanatic supporters of both sides. As P1 said:

'Kemalists that shout at women with headscarves', 'making tattoos with Ataturk's signatures'; 'the police [following the government's orders] targets people that drink beer on the streets'.

Three AKP supporters were angry at CHP and Kemalist forces that historically imposed rules of life and oppressed religious segments. A CHP supporter felt angry 


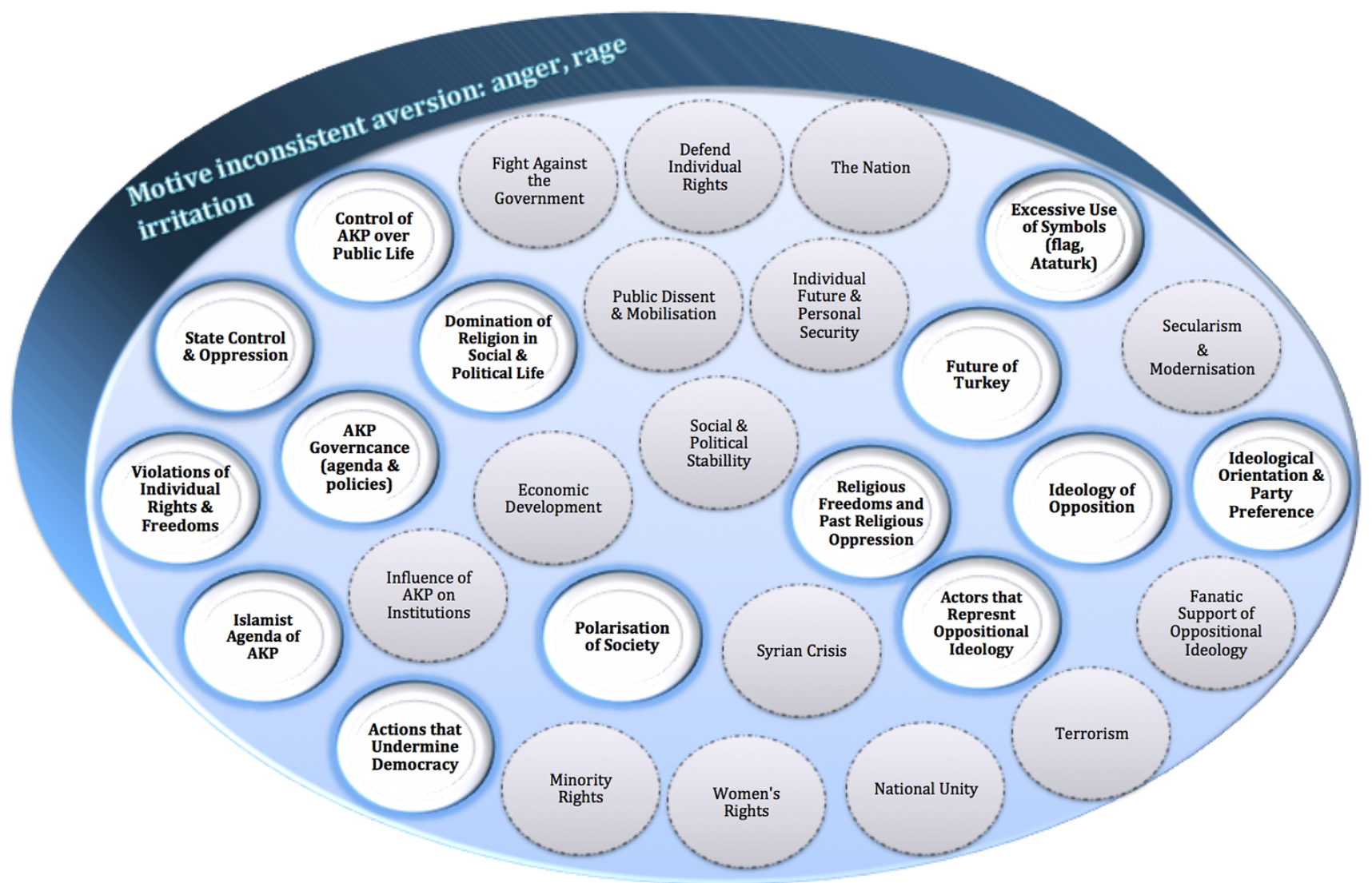

Figure 4. Map of motive inconsistent aversive affect.

because in the past citizens lived together but since 2005 tolerance decreased and polarization increased. 17 participants with divergent ideologies supported religious freedoms and the placement of religion in the private sphere, and the high levels of religiosity generated aversive emotions. Four socio-democrats CHP voters did not see the Islamic culture and traditions as posing a danger to the country and democracy, but expressed anger and frustration wanting religion to remain a private matter and society to be open for the individual expression of religious beliefs. Two AKP supporters acknowledged the importance of religion in Turkey, yet noted that all citizens should have religious freedom of expression. AKP supporters also expressed anger and annoyance against the past religious oppression generated by Kemalist elites.

As we saw earlier, symbols like the Turkish flag and pictures of Mustafa Kemal Ataturk were linked to aversive affect in addition to pride. Six noted the extensive use of both symbols in spaces such as banks, shops, restaurants and schools, which makes citizens feel that these are 'holy untouchable symbols' (P1) and that having the flag 'in every corner makes you feel that someone is trying to impose on you a sense of national identification' (P17). One AKP supporter and one anarchocommunist said that having the picture of Ataturk was undemocratic and closer to dictatorial systems. Two AKP voters felt angry seeing pictures of Ataturk everywhere although they respected the ideology he represented, while a nationalist MHP supporter felt angry with the Kurdish BDP:

BDP is under the control of PKK. It makes me very angry to know that a party is allowed to propagate in support of a terrorist organisation and play a legitimate role in politics. (P14)

For CHP and extreme-left supporters, aversive affect was also linked to value preferences towards individual freedoms and liberties and the role of women in society. They expressed anger when talking about mandatory military service, violence and attacks against LGTB people, social policies towards women in general, the enforcement of power and open provocations against oppositional voices, the expanding role of religion, the increase of Imam Hatip schools over secular education, and political life in general because 'there are no choices left for us anymore' (P1).

Motive inconsistent anxious affectivity was mapped in Figure 5. It was expressed as fear, worry, concern, anxiety, uncertainty and insecurity was mentioned 45 times often in combination with aversive and loss-related affectivity when discussing the political Islam-Kemalist conflict, the AKP domination, restrictions of freedom and individual rights, the AKP influence on the police and security forces, and the future of democracy. Items linked primarily to anxiety were minority and women's rights, 


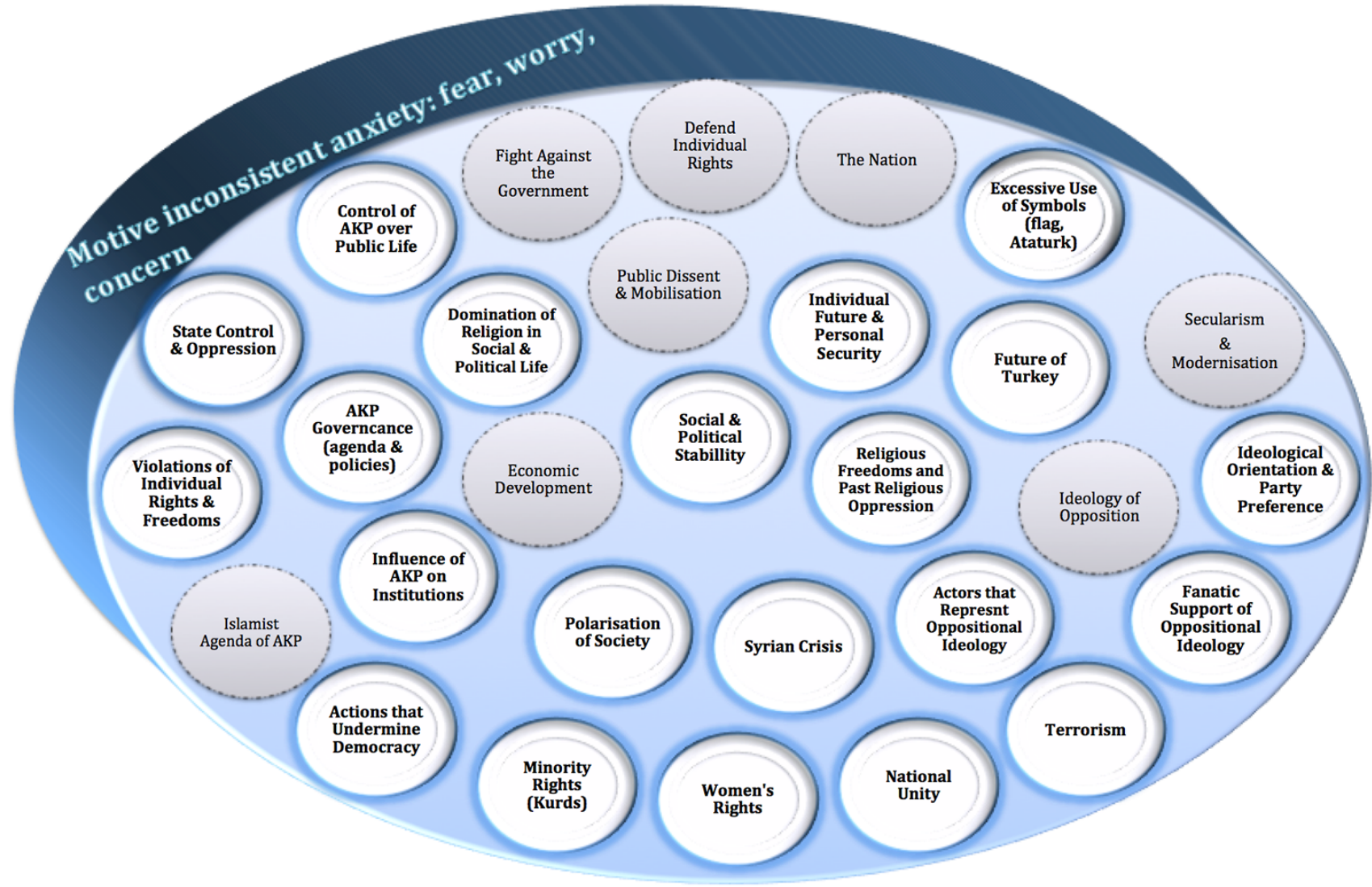

Figure 5. Map of motive inconsistent anxious affect.

the Syrian crisis, terrorism, fanaticism, and concerns over national unity. Ideological leanings were again important for these experiences.

Three extreme-left participants expressed fear towards fanatic Kemalists and political Islamists voting for CHP and AKP respectively, who 'legitimize social polarization and undermine the country's democratic establishment'. Another source of anxious feelings was social and political instability identifying specific social groups as threats (Kemalists, hard-line Islamists, Kurds, terrorist groups), depending on the participants' ideological and political orientation. According to P2:

Whoever wants to change the current situation and impose their own reality can play a significant destabilising role for Turkey. And these groups are many and too dangerous.

Citizens were also afraid of the high polarization, were anxious about the way social conflicts will unfold socially and politically, and tensions among friends, colleagues and family. An AKP supporter (P19) feared that once the economic state of Turkey starts 'the downward slide then tolerance will definitely collapse and underlying problems that are currently hidden will come to the surface'. $\mathrm{CHP}$ and extreme-left participants were scared to follow modern European-like lifestyles mentioning violations of individual rights and freedoms and state control over cit- izens, the AKP's oppression and the consequences for expressing views, beliefs or ideas that oppose the government and its status quo.

Uncertainty about the future of democracy was mentioned by two participants who worried about the increasing influence of the AKP government on security forces and the police. They had experienced fear of/or prosecution directly (themselves) or indirectly (their friends) and worried about the role of the police towards those that express dissent against the government or the Prime Minister. Two AKP supporters also expressed worry about the party's administration and future plans, and noted that by securing a healthy economy, social life would improve. CHP and extreme-left supporters expressed worry and uncertainty for the inability of other political agents to play a decisive role against AKP. As P23 noted:

I'm very worried about the future of democracy in Turkey. AKP has a very strong support and it seems that the more power they get the more invasive there are in the society with their practices.

Six female AKP opponents reported fears about Turkey's increasing Islamization and its impact on women. Four male extreme-left supporters and CHP voters were also afraid of compromises to women's rights to abortion. Eight AKP opponents expressed fear and concern for 
the country's future because of the increasing power acquired by Erdoğan and 'Turkey turning into a dictatorship'. A similar fear (concern for the future) was expressed by two liberal AKP supporters.

Finally we examined motive inconsistent loss-related affect in Figure 6. It was expressed as disappointment, distrust, and pessimism, mentioned by 21 participants, and appeared often alongside aversive and anxious affect.

AKP opponents expressed deep disappointment and pessimism about the increasing role of Islam, freedoms and human rights undermined by the AKP governance. As one participant noted:

I don't have trust for my future. Not anymore. I am even thinking of moving abroad maybe to Germany where I already have some family members. I am worried about how things will unfold; and what worries me the most is that no one feels free anymore to express opposition or an alternative position. If there was a healthy dialogue among political actors that would be one thing but when you lose that then you lose your hope.

\section{Discussion}

Our interviews in 2012 in Turkey point to complex affective experiences, which were neither static nor singular. Hope, pride, joy, anger, irritation, frustration, fear, worry, anxiety, uncertainty, sadness and disappointment were felt towards a variety of political objects, in complex blends and sometimes ambivalent systems. Our affective maps indicate the diverse sources of affect, drawing on considerations of religious or civic freedom, expressions of hope towards change and the strengthening of current conditions, anxious reactions towards security, the present and the unknown, disappointment for the state of democracy, pride for national symbols, and joy for how far the country has come. We also learned that affect aligned with ideological inclinations, confirming our hypothesis that emotions are differentiated by the appraisals of the events that trigger them. Based on the above, we think it is not meaningful for empirical models to split citizens into mainly angry, afraid or happy groups. Obtaining a deep understanding of what citizens think, feel and want allows for a better grasp not only of the mechanism that moves individual political behaviour but also of political process itself.

A critical examination of our study recognizes certain limitations. The small sample size does not allow us to perform powerful statistical analysis and significance testing. In addition, because our sample was nonprobabilistic the findings are not representative of the Turkish population. This is counter-balanced by being able to uncover the underexplored complexities of political affectivity. This study invites further investigations with larger interview samples, which will challenge sim-

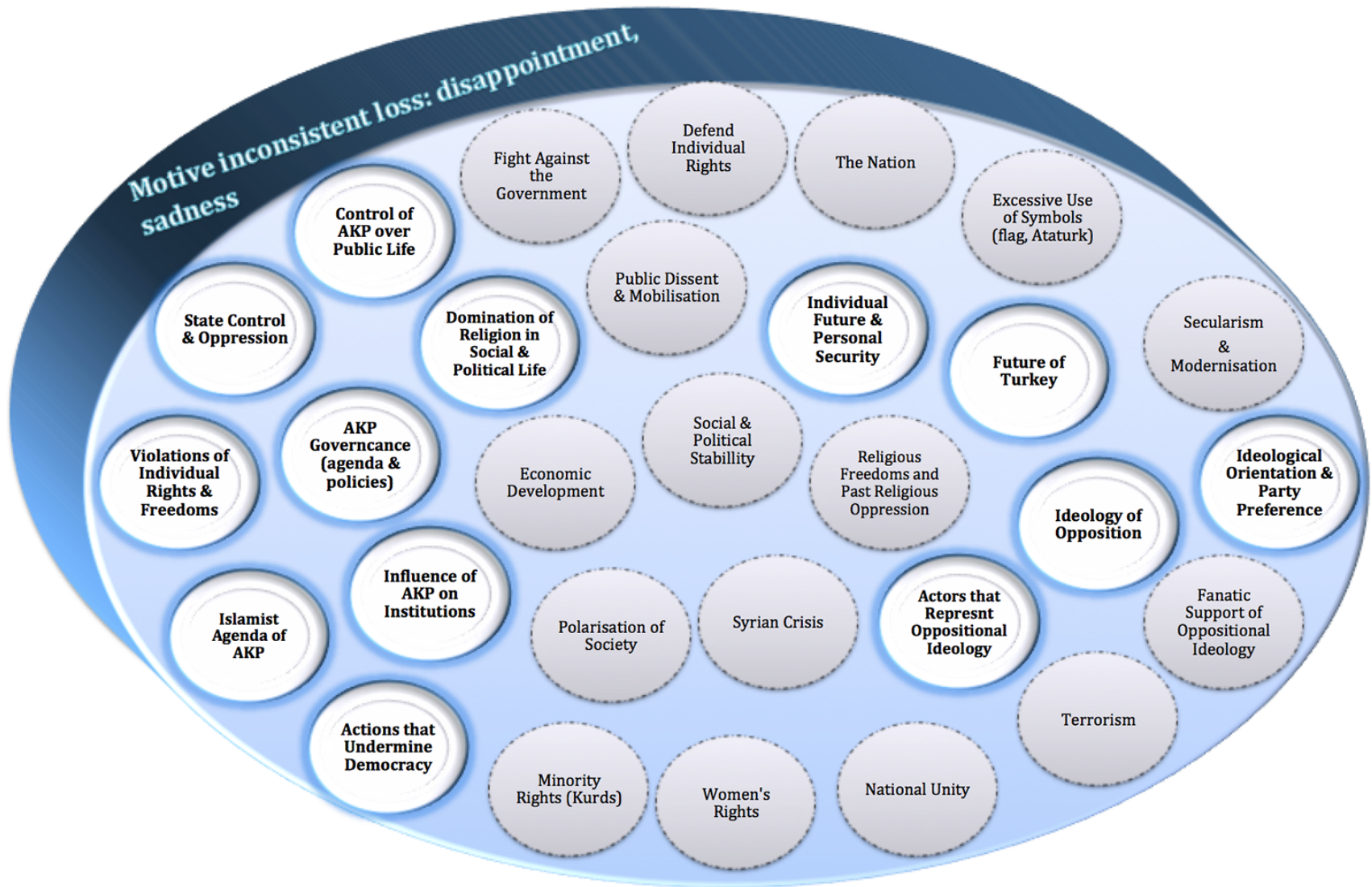

Figure 6. Map of motive inconsistent loss-related affect. 
plified approaches to emotions, and complement evidence on the significance of affect currently on offer by standard public opinion surveys.

By analysing our interview data with CAMs we were able to produce comparable maps of political concepts related to the expression of affectivity in Turkey. We focused on situational state (motive consistency versus inconsistency) and motivational state (gain or loss) appraisals to identify key affect-clusters. Future studies can expand to appraisals of power, legitimacy and agency. They can also measure appraisals directly, by asking participants to rate the event that caused their emotion on indicators of the hypothesized appraisals. For example, legitimacy predictions of a positive deserving outcome is characteristic of anger, but also pride, joy and hope, while a negative deserving outcome is characteristic of guilt (Scherer, 1988).

Our interview data allowed us to study naturally occurring affects recorded in the interviews rather than laboratory-induced emotions. So while authenticity is high, we are not able to test causal hypotheses. Experimentally induced emotions, moods or sentiments would have lower ecological validity but would gain in control of the scenarios manipulated. Experimental studies would be excellently suited to test the cause-effect links between specific event appraisals and their affective reactions (Capelos, 2013).

With the above in mind, the next step is to extend and replicate these findings using larger interview samples. Once the representativeness of the results is established, experimental and computational simulation models can test hypotheses about the role of specific affective clusters and their related appraisals on evaluations of specific political objects. Another promising and hitherto neglected area is to examine whether similar patterns are evident in group discussions and focus-group activities. This would allow for interesting comparisons between individual and collective affective experiences.

\section{Conclusion}

Since our 2012 interviews, Turkey has undergone a series of events that placed the country in an extended state of emergency that lasted for 2 years and left significant marks in the country's social and political spheres. Following Gezi and the 2016 attempted coup, the state launched a massive crackdown targeting all oppositional voices. This resulted in the arrest of thousands of civil servants from the armed forces, as well as teachers, academics, health workers and media representatives over alleged links with the Gülen movement. Many nongovernmental organisations working on human rights and individual freedoms were banned and closed down and political figures were imprisoned, on alleged connections with terrorist organisations (see the arrested members of the pro-Kurdish HDP).

A few studies looked at the recent changes in the public sphere offering insights into the way that the public and in particular activists organize and act (Bee, 2017; Bee \& Kaya, 2017). Several scholars have pointed to the creation of new social dynamics that relax the clear-cut boundaries of secularism-Islamism (Acar \& Uluğ, 2016; Bayramoğlu, 2009; Damar, 2016; Turam, 2015). The 2013 and 2016 political developments generated a new wave of strong emotions that shook again the social and political life of Turkey. Public sovereignty, democratic principles and individual rights and freedoms served as key mobilising agents, pointing to deep-rooted divisions and polarization even as the secularism-Islamism boundaries have become more fluid (Bayramoğlu, 2009; Capelos \& Chrona, 2012; Çarkoğlu \& Toprak, 2007; Göle, 2013; Turam, 2015).

A working hypothesis for future research is that the country's increasing authoritarianism outstrips the relaxed boundaries across existing divisions, reiterating and reinforcing new types of polarisation founded on traditionally oppositional ideologies. As Akarca and Başlevent (2011) put it, cultural, ethnic and socioeconomic elements that bring together segments of the population can create clear-cut divisions in the country's public sphere. Our findings suggest that ideological orientations shape different affective worlds; this could be the key for understanding how citizens negotiate their political identities amidst the current turbulent environment, and warrants further investigation.

We close with an invitation for the rigorous, comprehensive and systematic study of political affectivity. Moving beyond a handful of discrete emotions, towards a careful examination of the cognitive representations of specific affect clusters allows us to engage seriously with the content of expression of anger, hope, pride, joy, irritation, fear, worry, concern disappointment, loss in the Turkish context and beyond. Here we identified considerations that set these emotions apart, and others that connect them, as they form rich affective experiences. Evidence that emotions matter abounds, in recent studies that examine UK's Brexit, Trump's reactionary America, anti-globalization and anti-elite populist narratives, challenges of European integration, the gained support of far right, extreme and radical movements and parties, energy and climate change debates, the drivers and consequences of international crises of migration, the emotional economy of austerity politics, the internal functioning of international institutions (see Capelos \& Katsanidou, 2018; Salmela \& von Scheve, 2017; and in this issue Koschut, 2018; Palm, 2018; Sanchez Salgado, 2018; Skonieczny, 2018; Weber, 2018).

We found that affective reactions in 2012 in Turkey were rich, interconnected, ideologically consistent, and linked to evaluations of multiple political objects. Research on political affect can contribute to the in-depth study of intergroup and intercultural relations as well as current and future political developments in these heated times. Importantly, it can offer insights into the impact and viability of specific political models and practices in contemporary developed and developing democracies. 


\section{Acknowledgments}

We want to thank the Editors for including us in this project, the anonymous reviewers for their valuable comments and Madeleine Provost for her diligent proofreading of the article.

\section{Conflict of Interests}

The authors declare no conflict of interests.

\section{References}

Acar, Y. G., \& Uluğ, M. Ö. (2016). Examining prejudice reduction through solidarity and togetherness experiences among Gezi Park activists in Turkey. Journal of Social and Political Psychology, 4(1), 166-179.

Akarca, A. T., \& Tansel, A. (2007). Social and economic determinants of Turkish voter choice in the 1995 parliamentary election. Electoral Studies, 26, 633-647.

Akarca, A. T., \& Başlevent, C. (2011). Persistence in regional voting patterns in Turkey during a period of major realignment. European Urban and Regional Studies, 18(2), 184-202.

Arikan, G. (2013). Values, religiosity and support for redistribution and social policy in Turkey. Turkish Studies, 14, 34-52.

Bar-Tal, D., Halperin, E., \& de Rivera, J. (2007). Collective emotions in conflict situations: Societal implications. Journal of Social Issues, 63(2), 441-460.

Barrett, L. F. (2006). Are emotions as natural kinds? Perspectives on Psychological Science, 1, 28-58.

Başlevent, C., Kirmanioğlu, H., \& Şenatlar, B. (2009). Party preference and economic voting in Turkey (now that the crisis is over). Party Politics, 15(3), 377-391.

Bayramoğlu, A. (2009). Modernity does not tolerate superstition. The religious and seculars in the democratisation process. Istanbul: TESEV Publications.

BBC. (2013, June 1). Turkey police clash with Istanbul Gezi Park protesters. BBC. Retrieved from https:// www.bbc.co.uk/news/world-europe-22732139

Bee, C. (2017). Active citizenship in Europe. Demands and practices in the EU, Italy, Turkey and the UK. London: Palgrave.

Bee, C., \& Kaya, A. (2017). Between practices and demands: Ambiguities, controversies and constraints in the emergence of active citizenship in Turkey. Southeast European and Black Sea Studies, 17(3), 301-324.

Capelos, T. (2013). Understanding anxiety and aversion: The origins and consequences of affectivity in political campaigns. In N. Demertzis (Ed.), Emotions in politics: The affect dimension in political tension (pp. 39-59). Basingstoke: Palgrave Macmillan.

Capelos, T., \& Chrona, S. (2012). Islamist and nationalist attachments as determinants of political preferences in Turkey. Perceptions, Journal of International Affairs, 17(3), 51-80.
Capelos, T., \& Demertzis, N. (2018) Political action and resentful affectivity in critical times. Humanity and Society, 42(4), 410-433.

Capelos, T., Exadaktylos, T., Chrona, S., \& Poulopoulou, M. (2018). The emotional economy of the European financial crisis in the UK press. International Journal of Communication, 12, 2088-2113.

Capelos, T., \& Katsanidou, A. (2018). Reactionary politics: Uncovering the psychological roots of 'anti' preferences in European integration and immigration debates. Political Psychology, 36(9). https://doi.org/ 10.1111/pops. 12540

Capelos, T., Katsanidou, A., \& Demertzis, N. (2017). Back to black: Values, ideology and the black box of political radicalization. Science and Society, 35, 35-68.

Çarkoğlu, A. (2002). The rise of the new generation of pro-Islamists in Turkey: The justice and development party phenomenon in the November 2002 elections in Turkey. South European Society and Politics, 7(3), 123-156.

Çarkoğlu, A. (2007). A new electoral victory for the 'proIslamists' or the 'new centre right'? The justice and development party phenomenon in the July 2007 parliamentary elections in Turkey. South European Society and Politics, 12(4), 501-519.

Çarkoğlu, A., \& Hinich, M. J. (2006). A spatial analysis of Turkish party preferences. Electoral Studies, 25, 369-392.

Çarkoğlu, A., \& Kalaycioğlu, E. (2007). Turkish democracy today: Elections, protest and stability in an Islamic society. London: I. B. Tauris.

Çarkoğlu, A., \& Toprak, B. (2007). Religion, society and politics in a changing Turkey. Istanbul: TESEV Publications.

Chrona, S., \& Bee, C. (2017). Right to public space and right to democracy: The role of social media in Gezi Park. Research and Policy on Turkey, 2(1), 49-61.

Chrona, S., \& Capelos T. (2017). The political psychology of participation in Turkey: Civic engagement, basic values, political sophistication and the young. Southeast European and Black Sea Studies, 17(1), 77-95.

Ciddi, S. (2009). Kemalism in Turkish politics, the Republican People's Party, secularism and nationalism. London: Routledge.

Clore, G. L., \& Ortony, A. (2000). Cognitive in emotion: Never, sometimes, or always? In L. Nadel \& R. Lane (Eds.), The cognitive neuroscience of emotion (pp. 2461). New York, NY: Oxford University Press.

Conover, P. J., \& Feldman, S. (1984). How people organize the political world. American Journal of Political Science, 28, 95-126.

Converse, P. E. (1964). The nature of belief systems in mass politics. In D. E. Apter (Ed.), Ideology and discontent (pp. 206-261). New York, NY: Free Press.

Damar, E. (2016). Radicalization of politics and the production of new alternatives: Rethinking the secular/Islamic divide after the Gezi Park protests in Turkey. Journal of Contemporary European Studies, 
24(2), 207-222.

Damasio, A. (1994). Descartes' error. New York, NY: G.P. Putnam's Sons.

Damasio, A. (2003). Feelings of emotion and the self. Annals of the New York Academy of Sciences, 1001(1), 253-261.

Demertzis, N. (2013). Introduction: Theorizing the emotions-politics nexus. In N. Demertzis (Ed.), Emotions in politics: The affect dimension in political tension (pp. 1-16). Basingstoke: Palgrave Macmillan.

Denoeux, G. (2002). The forgotten swamp: Navigating political Islam. Middle East Policy, 9, 56-81.

Ekman, P. (2003). Emotions revealed: Recognizing face and feelings to improve communication and emotional life. New York, NY: Henry Holt and Co.

Erdoğan, E., \& Uyuan-Semerci, P. (2017). Understanding young citizens' political participation in Turkey: Does 'being young' matter? Southeast European and Black Sea Studies, 17, 57-75.

Erisen, C. (2013). Emotions as determinant in Turkish political behavior. Turkish Studies, 14, 15-135.

Erisen, C. (2016). An assessment on the behavioral foundations of electoral decisions in the 2015 Turkish general elections. Turkish Studies, 17, 47-57.

Erisen, C. (2017). Political behavior and the emotional citizen: Participation and reaction in Turkey. London: Palgrave Macmillan.

Esen, B., \& Gümüşüü, Ş. (2017). Turkey: How the coup failed. Journal of Democracy, 28(1), 59-73.

Esmer, Y. (2002). At the ballot box: Determinants of voting behaviour in Turkey. In Y. Esmer \& S. Sayarı (Eds.), Politics, parties and elections in Turkey (pp. 91-114). Boulder, CO: Lynn Rienner.

Ergünder, U. (1980-1981). Changing patterns of electoral behaviour in Turkey. Boğazici University Journal, 8/9, 45-81.

Fazio, R. H., Sanbonmatsu, D. M., Powell, M. C., \& Kardes, F. R. (1986). On the automatic activation of attitudes. Journal of Personality and Social Psychology, 50, 229-238.

Findlay, S. D., \& Thagard, P. (2014). Emotional change in international negotiation: Analyzing the Camp David accords using cognitive-affective maps. Group Decision and Negotiation, 23, 1281-1300.

Fiske, S. T., \& Taylor, S. E. (1984). Social cognition. Reading, MA: Addison-Wesley Pub. Co.

Frijda, N. H. (1986). The emotions. Cambridge: Cambridge University Press.

Frijda, N. H. (1994). Varieties of affect: Emotions and episodes, moods, and sentiments. In P. Ekman \& R. Davidson (Eds.), The nature of emotions: Fundamental questions (pp. 59-67). New York, NY: Oxford University Press.

Frijda, N. H. (2004). Emotions and action. In A. S. R. Manstead, N. Frijda, \& A. Fischer (Eds.), Studies in emotion and social interaction. Feelings and emotions: The Amsterdam symposium (pp. 158-173). New York, NY: Cambridge University Press.
Göle, N. (2013). Gezi-anatomy of a public square movement. Insight Turkey, 15(3), 7-14.

Gülalp, H. (2001). Globalization and political Islam: The social bases of Turkey's Welfare Party. International Journal of Middle Eastern Studies, 33(3), 433-448.

Hatfield, E., Caccioppo J. T., \& Rapson, R. L. (1994). Emotional contagion. Cambridge: Cambridge University Press.

Hochschild, A. R. (1979). Emotion work, feeling rules and social structure. American Journal of Sociology, 85(3), 551-575.

Homer-Dixon, T., Milkoreit, M., Mock, S. J., Schroder, T., \& Thagard, P. (2014). The conceptual structure of social disputes: Cognitive-affective maps as a tool for conflict analysis and resolution. SAGE Open, 4(1), $1-20$.

Jost, J. T., Nam, H. H., Amodio, D. M., \& Van Bavel, J. J. (2014). Political neuroscience: The beginning of a beautiful friendship. Political Psychology, 35(S1), $3-42$.

Kaya, A. (2015). Islamisation of Turkey under the AKP rule: Empowering family, faith and charity. South European Society and Politics, 20(1), 47-69.

Kentmen-Cin, C. (2015). Participation in social protests: Comparing Turkey with EU patterns. Southeast European and Black Sea Studies, 15(3), 223-237.

Koschut, S. (2018). Appropriately upset? A methodological framework for tracing the emotion norms of the transatlantic security community. Politics and Governance, 6(4), 125-134.

Lane, E. R. (1962). Political ideology. New York, NY: Free Press.

Lazarus, R. S. (1991). Emotion and adaptation. New York, NY: Oxford University Press.

Lazarus, R. S., Kanner, A., \& Folkman, S. (1980). Emotions: A cognitive-phenomenological analysis. In R. Plutchik, R., \& H. Kellerman (Eds.), Theories of emotion (pp. 189-217). New York, NY: Academic Press.

Mardin, Ş. (1973). Centre-periphery relations: A key to Turkish politics? Daedalus, 2, 169-191.

Markus, H., \& Zajonc, R. B. (1985). The cognitive perspective in social psychology. In G. Lindzey \& E. Anderson (Eds.), The handbook of social psychology (pp. 137-230). New York, NY: Random House.

Mullen, J., \& Cullinane, S. (2013, June 4). What's driving unrest and protests in Turkey? CNN. Retrieved from https://edition.cnn.com/2013/06/03/world/europe/ turkey-conflict-explainer/index.html

Odağ, Ö., Uluğ, Ö. M., \& Solak, N. (2016). 'Everyday I am çapuling': Çapulcu identity and collective action through social network sites in the Gezi Park protests. Journal of Media Psychology, 28, 148-159.

Öniş, Z. (2015). Monopolising the centre: The AKP and the uncertain path of Turkish democracy. The international spectator. Italian Journal of International Affairs, 50(2), 22-41.

Özbudun, E. (2006). From political Islam to conservative democracy: The case of the justice and development 
party in Turkey. South European Society and Politics, 11(3/4), 543-557.

Özdemir, E. (2015). An assessment of the Gezi protests in Turkey in 2013: Political agency as an articulation practice. Review of History and Political Science, 3(2), 51-58.

Palm, T. (2018). Interwar blueprints of Europe: Emotions, experience and expectation. Politics and Governance, 6(4), 135-143.

Reber, A. S. (1985). The Penguin dictionary of psychology. Harmondsworth: Penguin Books.

Rime, B. (2007). The social sharing of emotion as an interface between individual and collective processes in the construction of emotional climates. Journal of Social Issues, 63(2), 307-322.

Roseman, I. J., Spindel, M. S., \& Jose, P. E. (1990). Appraisals of emotion-eliciting events: Testing a theory of discrete emotions. Journal of Personality and Social Psychology, 59, 899-915.

Ross, A. (2014). Mixed emotions: Beyond fear and hatred in international conflict. Chicago, IL: Chicago University Press.

Russell, J. A. (1980). A circumplex model of affect. Journal of Personality and Social Psychology, 39, 1161-1178.

Sabini, J., \& Silver, M. (2005). Why emotion names and experiences don't neatly pair. Psychological Inquiry, 16, 1-10.

Salganic, M. J., \& Heckathorn, D. D. (2004). Sampling and estimation in hidden populations using respondentdriven sampling. Sociological Methodology, 34(1), 193-239.

Salmela, M., \& von Scheve, C. (2017). Emotional roots of right-wing political populism. Social Science Information, 56(4), 567-595.

Sanchez Salgado, R. (2018). The advocacy of feelings: Emotions in EU-based civil society organizations' strategies. Politics and Governance, 6(4), 103-114.

Scherer, K. R. (1984). On the nature and function of emotion: A component process approach. In K. R. Scherer \& P. Ekman (Eds.), Approaches to emotion (pp. 293-317). Hillsdale: Erlbaum.

Scherer, K. R. (1988). Cognitive antecedents of emotions. In V. Hamilton, G. H. Bower, \& N. H. Frijda (Eds.), Cognition, motivation and affect (pp. 89-126). Dordrecht: Nijhoff.

Scherer, K. R. (2001). Appraisal considered as a process of multilevel sequential processing. In K. R. Scherer, A. Schorr, \& T. Johnstone (Eds.), Appraisal processes in emotion: Theories, methods, and research (pp. 92-120). New York, NY: Oxford University Press.

Scherer, K. R. (2005). Unconscious processing in emotion: The bulk of the iceberg. In L. F. Barrett, P. M. Niedenthal, \& P. Winkielman (Eds.), Emotion and consciousness (pp. 312-334). New York, NY: Guilford.

Skonieczny, A. (2018). Emotions and political narratives: Populism, Trump and trade. Politics and Governance, 6(4), 62-72.
Snijders, T. A. B. (1992). Estimation on the basis of snowball samples: How to weight? Bulletin de Methodologie Sociologique, 36(1), 59-70.

Sniderman, P. M., Brody, R. A., \& Tetlock, P. E. (1991). Reasoning and choice: Explorations in political psychology. New York, NY: Cambridge University Press.

Somer, M. (2007). Moderate Islam and secularist opposition in Turkey: Implications for the world, Muslims and secular democracy. Third World Quarterly, 28(7), 1271-1289.

Taniyici, S. (2003). Transformation of political Islam in Turkey: Islamist Welfare Party's pro-EU turn. Party Politics, 9(4), 463-483.

Tansel, C. B. (2018). Authoritarian neoliberalism and democratic backsliding in Turkey: Beyond the narratives of progress. South European Society and Politics, 23(2), 197-217.

Thagard, P. (2006). Hot thought. Mechanisms and applications of emotional cognition. Cambridge, MA: The MIT Press.

Thagard, P. (2012). The cognitive science of science: Explanation, discovery, and conceptual change. Cambridge, MA: MIT Press.

Thagard, F., \& Findlay, S. D. (2014). Emotional change in international negotiation: Analyzing the Camp David accords using cognitive-affective maps. Group Decision and Negotiation, 23(6), 1281-1300.

Toros, E. (2014). Social indicators and voting: The Turkish case. Social Indicators Research, 115(3), 1011-1029.

Turam, B. (2015). Gaining freedoms: Claiming space in Istanbul and Berlin. Stanford, CA: Stanford University Press.

Uyusal, A. (2011). Continuity and rupture: the 'New CHP' or 'what has changed in the CHP'? Insight Turkey, 13(4), 129-146.

Weber, A.-K. (2018). The pitfalls of 'love and kindness': On the challenges of compassion/pity as a political emotion. Politics and Governance, 6(4), 53-61.

White, D., \& Herzog, M. (2016). Examining state capacity in the context of electoral authoritarianism, regime formation and consolidation in Russia and Turkey. Southeast European and Black Sea Studies, 16(4), 551-569.

Wolfe, S. E. (2011). Water cognition and cognitive affective mapping: Identifying priority clusters within a Canadian water efficiency community. Water Resources Management, 26, 2991-3004.

Yavuz, H. M. (2006). (Ed.). The emergence of a new Turkey, democracy and the AK Parti. Salt Lake City, UT: The University of Utah Press.

Yavuz, H. M. (2009). Secularism and Muslim democracy in Turkey. Cambridge: Cambridge University Press.

Yılmaz, O., Sarıbay, S. A., Bahçekapılı, H. G., \& Harma, M. (2016). Political orientations, ideological selfcategorizations, party preferences, and moral foundations of young Turkish voters. Turkish Studies, 17(4), 544-566. 


\section{About the Authors}

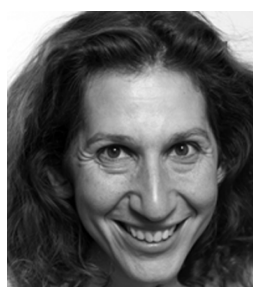

Tereza Capelos is Senior Lecturer in political psychology at the School of Government and Society, University of Birmingham, UK. Her research on political emotions, values and perceptions seeks to understand how citizens and elites form judgements and engage in political actions in times of crisis. Her recent publications examine the resentful affectivity and backward gazing values of political reactionism; the affective content of trust perceptions in international conflict; and the rich emotional economy of mediated debates during the financial crisis.

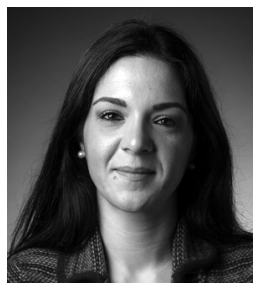

Stavroula Chrona is a Teaching Fellow in European and International Studies at the Department of European and International Studies at King's College London, UK. Her research focuses on the affective, cognitive and motivational determinants that shape citizens' political behavior, looking in particular at the role of ideological inclinations, sophistication, values and emotions. Her recent publications examine the affective content of citizens' political considerations in Turkey, the determinants of civic and political participation in authoritarianism and the emotional economy of the European financial crisis in the UK press. 